\title{
Plasma Testosterone Levels during the Testicular Cycle of the Redwinged Blackbird (Agelaius phoeniceus)
}

\author{
JOEL T. KERLAN ${ }^{1}$ AND ROBERT B. JAFFE ${ }^{2}$ \\ Depariments of Zoology and Obstetrics and Gynecology, University of Michigan, \\ Ann Arbor, Michigan 48104
}

Received July 5, 1973

\begin{abstract}
Fluctuations in plasma testosterone concentration during the testicular cycle of adult captive redwinged blackbirds were measured by radioimmunoassay. A peak in testosterone (range: $24.8-27.4 \mathrm{ng} / 10 \mathrm{ml}$ ) was associated with small testes that weighed less than $100 \mathrm{mg}$ in the photosensitive stage. In the regressive stage, testosterone concentration was uniformly low (mean $\pm \mathrm{SEM}: 6.6 \pm 0.6 \mathrm{ng} / 10 \mathrm{ml}$ ) over a range of gonadal weights (range: 6.5-799.8 mg). Surprisingly, testosterone was detected in birds in the refractory stage maintained on a long photoperiod for 35 days $(7.7 \pm 0.6 \mathrm{ng} / 10 \mathrm{ml})$ and in two birds kept for about 27 weeks (10.3 and $12.3 \mathrm{ng} / 10 \mathrm{ml}$ ). The relationship between plasma testosterone levels and the extent of testosterone synthesis by blackbird testes is discussed.
\end{abstract}

The regulatory mechanisms involved in the initiation and maintenance of photorefractoriness during the avian testicular cycle remains unresolved (for general reviews see Farner and Follett, 1966; Lofts and Murton, 1968; Lofts, 1970; Lofts et al., 1970). The modulating effects of intrahypothalamic implants of testosterone (Gogan, 1967, 1968; Gogan and Kordon, 1964; Kordon and Gogan, 1964, 1970; Wilson, 1970; Stetson, 1972; Cusick and Wilson, 1972) or cyproterone, an androgen antagonist (Cusick and Wilson, 1972) and intrahypophysial implants of testosterone (Stetson, 1972) suggest that photorefractoriness involves a negative androgen feedback on gonadotropic function.

Information on seasonal fluctuations of blood testosterone levels in birds has been reported only in the domestic duck (Garnier and Attal, 1970; Garnier, 1971). Although the testicular cycle of the domestic duck

1 Present address: Department of Biology, Hobart and William Smith Colleges, Geneva, New York 14456.

${ }^{2}$ Present address: Reproductive Endocrinology Center, Departmenl of Obsletrics and Gynecology, University of California, San Francisco, California 94143.

Copyright (C) 1974 by Academic Press, Inc. All rights of reproduction in any form reserved. includes a refractory stage, photorefractory drakes maintained on continuous light can resume testicular development (Benoit et al., 1950; Benoit, 1961) whereas this treatment extends photorefractoriness in many other species (Farner, 1959; Farner and Follett, 1966).

Recently, Payne (1969) and Kerlan (1972) have studied photorefractoriness in the redwinged blackbird (Agelaius phoeniceus). In contrast to the domestic duck, a long day length extended the refractory stage in blackbirds several months beyond the time of its natural termination (Kerlan, 1972). This observation provided the incentive to monitor changes in plasma testosterone during the testicular cycle. In the present study, plasma testosterone concentration was measured during the photosensitive (recrudescent), regressive, and refractory stages in captive adult male redwinged blackbirds.

\section{MATERIALS AND METHODS}

Adult male blackbirds were maintained at room temperature in large photoperiod rooms with a regimen of $18 \mathrm{hr}$ light (0800 to 0200$), 6 \mathrm{hr}$ dark (LD 18:6). The birds were not caged, but were 
allowed free flight within each room. Food (Purina Game Bird Chow-Finisher) mixed with mineralized grit and water were provided ad libitum. Vitamins (ABDEC Vitamins, Parke-Davis) were added to the water 1 day each week. Initial left testis size was estimated by laparotomy on all birds before they were placed in a photoperiod room, and changes in gonadal size were monitored on representative birds at selected intervals during each trial. Birds were classified in the photosensitive stage if testicular size increased markedly between two observations. On the other hand, birds that were observed to pass through the photosensitive stage and then displayed a significant reduction in testis size were considered to be in the regressive stage. Since minimal size gonads are not exclusive to the refractory stage (Hamner, 1968), only birds whose testes failed to enlarge after 1 month of exposure to the LD 18:6 regimen were considered photorefractory. In one experiment, the refractory stage was extended from July 15 to February 5 by continuous maintenance of the birds on this long photoperiod.

Blood was collected from decapitated birds, and the plasma was immediately frozen until assayed. Plasma was extracted twice with $5 \mathrm{ml}$ of benzene: hexane $(1: 2, \mathrm{v} / \mathrm{v})$ and quantitated by the method of Ismail et al. (1972). Although this method has not been specifically validated for bird plasma, plasma testosterone levels of redwinged blackbirds measured in this study fell within the range of values reported in other avian species (Rivarola et al., 1968; Jallageas and Attal, 1968; Furr, 1970; Jallageas and Assenmacher, 1970; Garnier, 1971).

\section{RESULTS}

Variation in plasma testosterone concentration during the testicular cycle is shown in Tables 1-3. In the photosensitive stage, the highest levels were associated with small testes that weighed less than $100 \mathrm{mg}$. It is of interest that an inverse relationship existed between testosterone concentration and testicular weight in birds with larger gonads during this stage. Minimal plasma levels in the photosensitive stage were associated with the largest testes. Plasma testosterone concentration during the regressive stage was diminished and relatively constant (mean $\pm \mathrm{SEM}: 6.6 \pm$ $0.6 \mathrm{ng} / 10 \mathrm{ml}$ ). The mean plasma testosterone level in photorefractory birds that had been maintained on a LD 18:6 regimen for 35 days was $7.7 \pm 0.6 \mathrm{ng} / 10 \mathrm{ml}$. It also was of interest to find that the mean plasma testosterone concentration in photorefrac-
TABLE 1

Variation of Plasma Testosteronf Concentration during the Photosensitive Stage

\begin{tabular}{|c|c|c|}
\hline $\begin{array}{c}\text { Testes weight } \\
\text { (mg) }\end{array}$ & $\begin{array}{c}\text { Plasma } \\
\text { testosterone } \\
(\mathrm{ng} / 10 \mathrm{ml})\end{array}$ & $\begin{array}{c}\text { Duration of } \\
\text { photostimu- } \\
\text { lation } \\
\text { (days) }\end{array}$ \\
\hline 23.7 & 15.5 & $17^{a}$ \\
\hline 37.9 & 24.8 & $17^{a}$ \\
\hline .53 .7 & 27.4 & $17^{a}$ \\
\hline 86.3 & 26.3 & $17^{a}$ \\
\hline 125.0 & 22.9 & $17^{b}$ \\
\hline 176.2 & 18.8 & $17^{a}$ \\
\hline 254.7 & 17.2 & $17^{a}$ \\
\hline 256.3 & 12.3 & $17^{a}$ \\
\hline 258.1 & 8.6 & $17^{a}$ \\
\hline 346.3 & 4.6 & $37^{c}$ \\
\hline 349.1 & 7.7 & $17^{a}$ \\
\hline 365.3 & 4.4 & $37^{c}$ \\
\hline
\end{tabular}

a March 17-April 2.

6 February 17-March 5.

c December 30-February 4.

TABLE 2

Variation of Plasma Testosterone CONCENTRATION DURING THF Regressive Stage

\begin{tabular}{|c|c|c|}
\hline $\begin{array}{c}\text { Testes weight } \\
\text { (mg) }\end{array}$ & $\begin{array}{c}\text { Plasma } \\
\text { testosterone } \\
(\mathrm{ng} / 10 \mathrm{ml})\end{array}$ & $\begin{array}{c}\text { Duration of } \\
\text { photostimu- } \\
\text { lation } \\
\text { (days) }\end{array}$ \\
\hline 799.8 & 4.9 & $14^{a}$ \\
\hline 562.4 & 6.4 & $14^{a}$ \\
\hline 318.7 & 8.8 & $71^{b}$ \\
\hline 172.2 & 6.9 & $71^{b}$ \\
\hline 73.8 & 7.9 & $45^{c}$ \\
\hline 61.4 & 7.0 & $45^{c}$ \\
\hline 28.9 & 4.9 & $14^{a}$ \\
\hline 22.9 & 5.1 & $14^{a}$ \\
\hline 22.5 & 5.2 & $45^{c}$ \\
\hline 18.1 & 4.9 & $45^{c}$ \\
\hline 6.5 & 11.0 & $71^{b}$ \\
\hline
\end{tabular}

a June 3-June 17.

${ }^{b}$ January 8-March 19 (days between laparotomy: $31,33,7$ ).

c March 25-May $5(38,7)$.

tory birds maintained on a LD 18:6 regimen for about 1 month was not statistically different from the average level during the regressive stage. Moreover, in a preliminary 
TABLE 3

Variation of Ptasma Thistosteronf: Concentration DURing THE REFRACTORY STAGE

\begin{tabular}{ccc}
$\begin{array}{c}\text { Testes weight } \\
\text { (mg) }\end{array}$ & $\begin{array}{c}\text { Plasma } \\
\text { testosterone } \\
(\mathrm{ng} / \mathbf{1 0} \mathrm{ml})\end{array}$ & $\begin{array}{c}\text { Duration of } \\
\text { photostimulation } \\
\text { (days) }\end{array}$ \\
\hline 7.3 & 7.3 & $35^{a}$ \\
6.9 & 9.6 & $35^{a}$ \\
6.4 & 7.2 & $35^{a}$ \\
5.7 & 7.3 & $35^{a}$ \\
4.0 & 8.7 & $35^{a}$ \\
2.3 & 4.6 & $35^{a}$ \\
2.1 & 9.3 & $35^{a}$ \\
$\mathbf{6 . 5}$ & 12.3 & $205^{b}$ \\
$\mathbf{3 . 5}$ & 10.3 & $205^{b}$ \\
\hline
\end{tabular}

a July 31-September 3 .

'July 15-February 4 (days between laparotomy: $62,39,68,36$ ).

study of extended photorefractoriness, two birds which had been maintained in a refractory condition for approximately 27 weeks had testosterone concentrations of 10.3 and $12.3 \mathrm{ng} / 10 \mathrm{ml}$.

\section{DISCUSSION}

The plasma testosterone concentration in redwinged blackbirds falls within the range of values reported in other avian species. Maximum testosterone levels in blackbirds are higher than in quail (Jallageas and Attal, 1968) and in pigeons (Jallageas and Attal, 1968; Rivarola et al., 1968), comparable to maximal levels in domestic ducks (Jallageas and Attal, 1968; Jallageas and Assenmacher, 1970; Garnier, 1971), but lower than in roosters (Furr, 1970). It should be noted that the method of radioimmunoassay used here does not involve chromatographic isolation of dihydrotestosterone, and this steroid displays considerable activity in the system. Therefore, estimates of plasma testosterone levels might be elevated. However, in an earlier study of blackbird testes, we failed to detect the in vitro production of dihydrotestosterone from radiolabeled pregnenolone and progesterone (Kerlan et al., 1973).

The similarity between testosterone levels in birds with large testes in the photosensitive stage and regressive stage suggests that the decline in plasma testosterone concentration precedes testicular regression. This is in agreement with studies of plasma testosterone levels in the duck (Jallageas and Assenmacher, 1970; Garnier, 1971). In the duck, testicular vein testosterone concentration also decreases prior to gonadal regression (Garnier and Attal, 1970). The depression of plasma testosterone concentration in blackbirds is consistent with the observation that in vitro production of testosterone is low in large testes during the regressive stage (Kerlan et al., 1973).

In redwinged blackbirds, marked discrepancies exist between plasma testosterone concentration and the capacity for testosterone biosynthesis in vitro during the same period of the testicular cycle, and often in the same bird. We have reported that a second increase in testosterone formation in vitro occurs in small testes in the regressive stage (Kerlan et al., 1973). This increase in testosterone synthesis, however, is not associated with an elevation in plasma testosterone concentration. This difference may reflect a decrease in testosterone permeability of the blood-testis barrier serving to retain testosterone within the testis. The physiological role of testosterone during this period is unknown.

The detection of circulating testosterone in the refractory stage was surprising, as testosterone formation from isotopic precursors could not be detected in these testes (Kerlan et al., 1973). This discrepancy may result either from the rapid conversion of testosterone to other steroids during the incubation or the extragonadal secretion of testosterone, perhaps by the adrenals. The latter explanation is consistent with the finding of testosterone in the plasma of ducks 1 month after castration (Jallageas and Assenmacher, 1970).

This preliminary report of the quantitation of plasma testosterone during the refractory stage of redwinged blackbirds is consistent with the concept of inhibitory androgen feedback of gonadotropic function.

\section{ACKNOWLEDGMENTS}

We wish to thank Professor B. E. Frye for his critical evaluation of an earlier draft of this manu- 
script. We also wish to thank J. Huss for technical assistance in measuring plasma testosterone concentration and John Seubert, Brooke Meanley, and Mildred Miskimen of the Bureau of Sport Fisheries and Wildlife for the supply of blackbirds. This work was supported, in part, by a Ford Foundation Predoctoral Fellowship to J. T. K.

\section{REFERENCES}

Benoit, J. (1961). Opto-sexual reflex in the duck: Physiological and histological aspects. Yale J. Biol. Med. 34, 97-116.

Benoit, J., Assenmacher, I., and Walter, F. X. (1950). Résponses du mécanisme gonadostimulant à l'eclairement artificiel et de la préhypophyse aux castrations bilatérale et unilaterale, chez le canard domestique mâle, au cours de la période de régression testiculaire saisonniére. C. R. Soc. Biol. 144, 573-577.

Cusick, E. K., And Wilson, F. E. (1972). On control of spontaneous testicular regression in Tree Sparrows (Spizella arborea). Gen. Comp. Endocrinol. 19, 441-456.

Farner, D. S. (1959). Photoperiodic control of annual gonadal cycles in birds. In "Photoperiodism and Related Phenomena in Plants and Animals" (R. B. Withrow, ed.), pp. 717750. AAAS, Washington, D. C.

Farner, D. S., and Follett, B. K. (1966). Light and other factors affecting avian reproduction. J. Anim. Sci., Suppl. 25, 90-118.

Furr, B. J. A. (1970). Estimation of testosterone in plasma of the domestic fowl. J. Endocrinol. 48, xlii.

Garnier, D. H. (1971). Variations de la testostérone du plasma périphérique chez le Canard Pékin au cours du cycle annual. C.R. Acad. Sci. Ser. $D$ 272, 1665-1668.

Garnier, D. H., and Attal, J. (1970). Variations de la testostérone du plasma testiculaire et des cellules interstitielles chez le Canard Pekin au cours du cycle annual. C. R. Acad. Sei. Ser. D 270, 2472-2475.

Gogan, F. (1967). Action de la testostérone sur la gonadostimulation par la lumière chez le Canard Pékin. Biol. Med. 56, 369-376.

Gogan, F. (1968). Sensibilité hypothalamique à la testostérone chez le Canard. Gen. Comp. Endocrinol. 11, 316-327.

Gogan, F., and Kondon, C. (1964). Influence du feed-back par la testostérone sur gonadostimulation induite par la lumiére chez le canard. $J$. Physiol. (Paris) 56, 364-365.

HaMner, W. (1968). The photorefractory period of the House Finch. Ecology 49, 211-228.

Ismail, A. A. A., Niswender, G. D., ANd Midgley,
A. R., JR. (1972). Radioimmunoassay of testosterone without chromatography. J. Clin. Endocrinol. Metab. 34, 177-184.

Jallageas, M., and AtTal, J. (1968). Dosage par chromatographie en phase gazeuse de la testostérone plasmatique non conjuguée chez le Canard, la Caille, le Pigeon. C. R. Acad. Sci. Ser. $D$ 267, 341-343.

Jallageas, M., and Assenmacher, I. (1970). Testostéronémie du Canard photostimulé ou soumis á injections répétées de testosterone. $C$. $R$. Soc. Biol. 164, 2338-2341.

KerLAN, J. T. (1972). The testicular cycle in adult captive Redwinged Blackbirds (Agelaius phoeniceus). A comparison of changes in testis size, testosterone and 20-hydroxyprogestin formation, plasma testosterone concentration, and mouth lining color. Doctoral Disscrtation, University of Michigan, Ann Arbor.

Kerlan, J. T., Jaffe, R. B., and Payne, A. H. (1973). Sex steroid formation in gonadal tissue homogenates during the testicular cycle of the Redwinged Blackbird (Agelaius phoeniceus). Submitted for publication.

Kordon, C., and Gogan, F. (1964). Localisation par une technique de microimplantation de structures hypothalamiques responsables $\mathrm{du}$ feed-back par la testostérone chez le Canard. C. R. Soc. Biol. 158, 1795-1798.

Kordon, C., ANd Gogan, F. (1970). Interaction du feed-back et de la photostimulation dans les régulations gonadotropes chez les mammifères et les oiseaux. In "La Photorégulation de la Reproduction chez les Oiseaux et les Mammifères" (J. Benoit et I. Assenmacher, eds.). Colloq. Int. Cent. Nat. Rech. Sci. 172, 325-350.

LoFTs, B. (1970). Cytology of the gonads and feedback mechanisms with respect to photosexual relations in male birds. In: "La Photorégulation de la Reproduction chez les Oiseaux et les Mammifères" (J. Benoit et I. Assenmacher, eds.). Colloq. Int. Cent. Nat. Rech. Sci. 172, 307-323.

Lofts, B., And Murton, R. K. (1968). Photoperiodic and physiological adaptions regulating avian breeding cycles and their ecological significance. J. Zool. (London) 155, 327-394.

Lofts, B., Follett, B. K., and Murton, R. K. (1970). Temporal changes in the pituitary-gonadal axis. Mem. Soc. Endocrinol. 18, 545-575.

Payne, R. B. (1969). Breeding seasons and reproductive physiology of Tricolored Blackbirds and Redwinged Blackbirds. Univ. Calif. Publ. Zool. 90, 1-137.

Rivarola, M. A., Snipes, C. A., and Migeon, C. J. (1968). Concentrations of androgens in sys- 
temic plasma of rats, guinea pigs, salamanders and pigeons. Endocrinology 82, 115-121.

Stetson, M. H. (1972). Feedback regulation of testicular function in Japanese quail: Testosterone implants in the hypothalamus and adenohypophysis. Gen. Comp. Endocrinol. 19, 37-47.
Wilson, F. E. (1970). The tubero-infundibular neuron region of the hypothalamus: A focus of testosterone sensitivity in male Tree Sparrows (Spizella arborea). Proc. Int. Symp. Neurosecretion 6th, pp. 274-286. 